\title{
ASPEK PERTANGGUNGJAWABAN PIDANA NOTARIS PADA PEMBUATAN AKTA PIHAK (STUDI PUTUSAN MAHKAMAH AGUNG NOMOR 1099/PID/2010)
}

\author{
ASPECTS ACCOUNTABILITY CRIMINAL NOTARY IN MAKING \\ THE BIRTH CERTIFICATE PARTY (STUDY DECISIONS OF THE \\ SUPREME COURT NUMBER 1099 / PID / 2010)
}

Gde Yogi Yustyawan

Notaris/ppat I gede raka sukarta sh Email : yogikyustyawan@yahoo.com

Siti Hamidah

Universitas Brawijaya

Email : hamidah@ub.ac.id

\section{Hariyanto Susilo}

Universitas Brawijaya

Email : hariyantosusilo@ub.ac.id

Naskah diterima : 18/07/2018; direvisi : 27/07/2018; disetujui : 27/07/2018

\begin{abstract}
In making an authentic deed certainly Notary not separated by what is called responsibility for all actions or deeds. Accountability is an attitude or action to bear all the consequences of the deed done or the attitude to bear all the risks or consequences resulting from an act. The responsibility is determined by the nature of the violation and the resulting legal consequences. While the responsibility of a notary in the Law of Position Notary is intended as an attachment of a Notary to the legal provisions in performing its duties and obligations.
\end{abstract}

Key Words : Authentic, Notary Responsibility,

\begin{abstract}
Abstrak
Dalam membuat akta otentik tentu Notaris tidak lepas dengan apa yang dinamakan tanggung jawab atas semua tindakan atau perbuatannya. Pertanggungjawaban merupakan suatu sikap atau tindakan untuk menanggung segala akibat dari perbuatan yang dilakukan atau sikap untuk menanggung segala resiko ataupun kosekuensinya yang ditimbulkan dari suatu perbuatan.Pertanggungjawaban itu ditentukan oleh sifat pelanggaran dan akibat hukum yang ditimbulkannya. Sedangkan tanggung jawab notaris dalam Undang-Undang Jabatan Notaris dimaksudkan sebagai keterikatan Notaris terhadap ketentuan-ketentuan hukum dalam menjalankan tugas dan kewajibannya.
\end{abstract}

Kata Kunci : Autentik, Tanggungjawab Notaris 


\section{PENDAHULUAN}

Perlindungan hukum terhadap Notaris dalam menjalankan tugas dan wewenangnya demi terlaksananya fungsi pelayanan dan tercapainya kepastian hukum dalam memberikan pelayanan kepada masyarakat, telah diatur dalam Undang-Undang Nomor 2 Tahun 2014 tentang perubahan atas Undang-Undang Nomor 30 Tahun 2004 tentang Jabatan Notaris. Pasal 1 angka 1 UndangUndang Nomor 2 Tahun 2014 tentang perubahan atas Undang-Undang Nomor 30 Tahun 2014 tentang Jabatan Notaris menentukan "Notaris adalah pejabat umum yang berwenang untuk membuat akta otentik dan memiliki kewenangan lainnya sebagaimana dimaksud dalam undang-undang ini atau berdasarkan undang-undang lainnya." Notaris dikatakan sebagai pejabat umum karena Notaris diangkat dan diberhentikan oleh pemerintah tetapi tidak bisa disamakan dengan pegawai negeri, yang membedakan adalah notaris pegawai pemerintah tetapi tidak serta merta di gaji oleh pemerintah.

Berlakunya Undang-Undang Jabatan Notaris diharapkan bahwa akta otentik yang dibuat oleh atau di hadapan Notaris mampu menjamin kepastian, ketertiban, dan perlindungan hukum.Dalam UndangUndang Jabatan Notaris telah diatur tentang kewenangan Notaris pada Pasal 15 ayat (1) yang menyebutkan bahwa Notaris berwenang membuat Akta autentik mengenai semua perbuatan, perjanjian, dan penetapan yang diharuskan oleh peraturan perundang-undangan dan/ atau yang dikehendaki oleh yang berkepentingan untuk dinyatakan dalam Akta autentik, menjamin kepastian tanggal pembuatan Akta, menyimpan Akta, memberikan grosse, salinan dan kutipan Akta, semuanya itu sepanjang pembuatan Akta itu tidak juga ditugaskan atau dikecualikan kepada pejabat lain atau orang lain yang ditetapkan oleh undang-undang. Disamping itu dalam Pasal 15 ayat (2) Undang-Undang Jabatan Notaris menyatakan Notaris berwenang mengesahkan tanda tangan dan menetapkan kepastian tanggal surat di bawah tangan dengan mendaftar dalam buku khusus, membukukan surat di bawah tangan dengan mendaftar dalam buku khusus, membuat kopi dari asli surat di bawah tangan berupa salinan yang memuat uraian sebagaimana ditulis dan digambarkan dalam surat yang bersangkutan, melakukan pengesahan kecocokan fotokopi dengan surat aslinya, memberikan penyuluhan hukum sehubungan dengan pembuatan akta, membuat akta yang berkaitan dengan pertanahan, dan membuat akta risalah lelang. Berdasarkan kewenangan tersebut Notaris dipercayakan oleh masyarakat dalam membuat akta otentik.

Undang-Undang Jabatan Notaris Pasal 1 angka 7 menyatakan bahwa "akta autentik yang dibuat oleh atau di hadapan Notaris menurut bentuk dan tata cara yang ditetapkan dalam Undang-Undang ini." Akta otentik yang dimaksud adalah akta otentik sesuai dengan rumusan Pasal 1868 Kitab Undang-Undang Hukum Perdata yaitu "Suatu akta otentik ialah akta yang didalam bentuk yang ditentukan oleh undang-undang, dibuat oleh atau dihadapan pegawai-pegawai umum yang berkuasa untuk itu di tempat dimana akta itu dibuat."

Akta yang dibuat oleh Notaris mempunyai peranan penting dalam menciptakan kepastian hukum di dalam setiap hubungan hukum, sebab akta Notaris bersifat otentik, dan merupakan alat bukti terkuat dan terpenuh dalam setiap perkara yang terkait dengan akta Notaris tersebut. Dalam pembuatan akta otentik tertentu ada yang diharuskan oleh peraturan perundang-undangan dalam rangka menciptakan kepastian ketertiban dan perlindungan hukum. Pembuatan akta demikian tidak saja karena 
diharuskan oleh peraturan perundangundangan, tetapi juga karena dikehendaki oleh pihak yang berkepentingan untuk memastikan hak dan kewajiban para pihak yang berkepentingan demi kepastian, ketertiban dan perlindungan hukum bagi pihak yang berkepentingan sekaligus bagi masyarakat secara keseluruhan. Akta Notaris adalah akta autentik yang dibuat oleh atau di hadapan Notaris menurut bentuk dan tata cara yang ditetapkan dalam Undang-Undang. Sehingga, ada dua macam/golongan akta notaris, yaitu relaas akta dan partij akta. Relass akta adalah akta yang dibuat oleh notaris memuat uraian secara otentik dari notaris mengenai suatu tindakan yang dilakukan atau suatu keadaan yang dilihat atau disaksikan oleh notaris sedangkan partij akta adalah akta yang dibuat di hadapan notaris memuat uraian dari apa yang diterangkan atau diceritakan oleh para pihak yang menghadap kepada notaris. Akta otentik pada hakekatnya memuat kebenaran formal sesuai dengan apa yang diberitahukan para pihak kepada Notaris. Demikian Notaris mempunyai kewajiban untuk memasukkan bahwa apa yang termuat dalam akta Notaris sungguh-sungguh telah dimengerti dan sesuai dengan kehendak para pihak, yaitu dengan cara membacakannya, sehingga menjadi jelas isi akta Notaris tersebut. ${ }^{1}$

Akta otentik merupakan alat bukti tulisan atau surat yang bersifat sempurna. Akta otentik memiliki 3 (tiga) kekuatan pembuktian yaitu kekuatan pembuktian lahiriah (uitwendige bewijskracht) yang merupakan kemampuan akta itu sendiri untuk membuktikan keabsahannya sebagai akta otentik (acta publica probant sese ipsa), kekuatan pembuktian formal (formele bewijskracht) yang memberikan kepastian bahwa suatu kejadian dan fakta tersebut betul-betul dilakukan oleh

${ }^{1}$ Sjaifurrachman dan Habib Adjie, Aspek Pertanggungjawaban Notaris dalam Pembuatan Akta, (Bandung: Mandar Maju, 2011), hlm. 10.
Notaris atau diterangkan oleh pihak-pihak yang menghadap pada saat yang tercantum dalam akta sesuai dengan prosedur yang sudah ditentukan dalam pembuatan akta, sedangkan kekuatan pembuktian materil (materiele bewijskracht) merupakan kepastian tentang materi suatu akta, bahwa apa yang tersebut dalam akta merupakan pembuktian yang sah terhadap pihak-pihak yang membuat akta atau mereka yang mendapat hak dan berlaku untuk umum, kecuali ada pembuktian sebaliknya (tegenbewijs). ${ }^{2}$

Tanggung jawab lahir sebagai akibat dari adanya kewenangan yang dimiliki oleh masyarakat. Wewenang merupakan suatu tindakan hukum yang diatur dan diberikan pada suatu jabatan berdasarkan peraturan perundang-undangan yang berlaku yang mengatur jabatan yang bersangkutan. ${ }^{3}$ Setiap wewenang memiliki batasan, sebagaimana yang tercantum dalam peraturan perundang-undangan yang mengaturnya. Wewenang yang dimiliki notaris merupakan wewenang atribusi, yaitu wewenang yang melekat pada suatu jabatan.Wewenang yang dimiliki notaris merupakan akibat dari jabatan yang diembannya. Secara umum kewenangan Notaris selaku pejabat umum adalah membuat akta otentik. Pasal 15 Ayat (1) Undang-Undang Nomor 2 Tahun 2014 Tentang Perubahan Atas Undang-Undang Nomor 30 Tahun 2004 telah menjelaskan tentang kewenangan Notaris yaitu Notaris berwenang membuat akta otentik mengenai semua perbuatan, perjanjian, dan ketetapan yang diharuskan oleh peraturan perundangundangan dan/atau yang dikehendaki oleh yang berkepentingan untuk dinyatakan dalam akta otentik, menjamin kepastian tanggal pembuatan akta, menyimpan akta, memberikan grosse, Salinan dan kutipan akta, semuanya itu sepanjang pembuatan

\footnotetext{
${ }^{2}$ Habib Adjie, Kebatalan dan Pembatalan Akta Notaris, (Bandung: PT Refika Aditama, 2011), hlm. 18.

${ }^{3}$ Habib Adjie, Hukum Notaris Indonesia, (Bandung: PT Refika Aditama, 2009), hlm. 5.
} 
akta-akta itu tidak juga ditugaskan atau dikecualikan ke pada pejabat lain atau orang lain yang ditetapkan oleh undangundang. Kedudukan Notaris sebagai pejabat umum dalam arti kewenangan yang ada pada Notaris tidak pernah diberikan kepada pejabat lainnya selama atau sepanjang kewenangan tersebut tidak diberikan atau tidak menjadi kewenangan pejabat-pejabat lain dalam membuat akta otentik dan kewenangan lainnya, maka kewenangan tersebut menjadi kewenangan Notaris. Berdasarkan penjelasan diatas Pertanggungjawaban notaris terhadap akta yang dibuatnya adalah secara perdata notaris hanya bertanggung jawab kepala akta, berarti yang berisikan terhadap kewenangan para penghadap dalam menandatangani akta, selanjutnya terhadap penutup akta yang berisi kewenangan saksi-saksi kemudian dihadapkan oleh para penghadap untuk menandatangani akta, sedangkan terhadap isi akta notaris hanya bertanggung jawab bahwa akta yang dibuatnya tidak melanggar klausul-klausul yang dilarang oleh Undang-Undang dan norma kepatutan yang ada di dalam masyarakat sebagaimana disebutkan dalam Pasal 1337 KUHPerdata. ${ }^{4}$

Dalam membuat akta otentik tentu Notaris tidak lepas dengan apa yang dinamakan tanggung jawab atas semua tindakan atau perbuatannya. Pertanggungjawaban merupakan suatu sikap atau tindakan untuk menanggung segala akibat dari perbuatan yang dilakukan atau sikap untuk menanggung segala resiko ataupun kosekuensinya yang ditimbulkan dari suatu perbuatan. Pertanggungjawaban itu ditentukan oleh sifat pelanggaran dan akibat hukum yang ditimbulkannya. Sedangkan tanggung jawab notaris dalam UndangUndang Jabatan Notaris dimaksudkan sebagai keterikatan Notaris terhadap

${ }^{4}$ Liliana Tedjosaputro, Etika Profesi dan Profesi Hukum, (Semarang: Aneka Ilmu, 2003), hlm 93. ketentuan-ketentuan hukum dalam menjalankan tugas dan kewajibannya. Secara umum pertanggungjawaban yang biasa dikenakan terhadap Notaris adalah pertanggungjawaban pidana, administrasi dan perdata. Pertanggungjawaban secara pidana dijatuhi sanksi pidana, pertanggungjawaban admistrasi dijatuhi sanksi administrasi, sedangkan pertanggungjawaban perdata dijatuhi sanksi perdata. Itu merupakan konsekuensi dari akibat pelanggaran atau kelalaian yang dilakukan oleh Notaris dalam proses pembuatan akta otentik.

Menentukan adanya suatu pertanggungjawaban secara perdata atau pidana yang dilakukan oleh seorang Notaris harus dipenuhi tiga syarat, yaitu harus ada perbuatan Notaris yang dapat dihukum yang unsur-unsurnya secara tegas dirumuskan oleh undang-undang, perbuatan Notaris tersebut bertentangan dengan hukum, serta harus ada kesalahan dari Notaris tersebut. Kesalahan atau kelalaian dalam pengertian pidana meliputi unsur-unsur bertentangan dengan hukum. Notaris tidak dapat dilepaskan dari perbuatan yang menyimpang. Karena seorang Notaris tetap seorang manusia biasa yang tak luput dari kesalahan. Notaris harus siap untuk menghadapi jika sewaktu-waktu dijadikan pihak yang terlibat dalam perkara bidang Hukum Perdata maupun Pidana, yang diakibatkan dari produk hukum yang dibuatnya. Oleh karena itu akibat dari produk hukum yang dibuatnya terlibat dalam perkara baik dalam bidang hukum perdata maupun pidana maka notaris tersebut telah ditetapkan sebagai tersangka, terdakwa dan dipidana.

Undang-Undang Nomor 2 Tahun 2014 Tentang perubahan Atas Undang-Undang Nomor 30 Tahun 2004 Tentang Jabatan Notaris telah mengatur tentang kewajiban, kewenangan, serta sanksi terhadap Notaris dalam pembuatan akta otentik tetapi dalam faktanya banyak notaris 
tidak dijatuhi hukuman sebagaimana mestinya atau tidak sesuai dengan aturan yang belaku oleh sebab itu timbul beberapa masalah terhadap aturan atau norma yang tepat yang harus diterapkan kepada Notaris yang melanggar hukum terhadap pembuatan akta otentik. Maka dari itu sangat penting untuk dilakukanya penelitian terhadap pertanggungjawaban Notaris dalam pembuatan akta otentik serta sanksi yang tepat dijatuhi terhadap Notaris tersebut agar menimbulkan kepastian hukum bagi Notaris itu sendiri

Saat ini banyak ditemukan kasus yang menjerat Notaris ke pengadilan mulai dari kasus perdata maupun kasus pidana serta sudah ada yang dijatuhi putusan pengadilan. Adapun yurisprudensi mengenai Notaris yang dijatuhi putusan pidana Putusan Mahkamah Agung nomor 1099 K/PID/2010 jucto putusan Pengadilan Tinggi Medan nomor 82/ PID/2010/PT-MDN jucto putusan Pengadilan Negeri Medan Nomor 3036/ PID.B/2009/PN.MDN yang gambaran kasusnya sebagai berikut:

Bermula ketika IR DULANG MARTAPA selaku penjual dari PT.Ira Widya Utama melakukan kesepakatan dalam hal berjanji dan mengikat diri akan menjual dan memindahkan serta menyerahkan 17 (tujuh belas) kavling tanah yang terletak di Komplek Bukit Hijau Regency yang terdiri dari 21 (duapuluh satu) Sertifikat Hak Guna Bangunan yang terdaftar pada Kantor Pertanahan Kota Medan atas nama PT Ira Widya Utama, serta sebidang tanah seluas 4.269,66 m2. Selanjutnya telah disepakati batas tanah yang akan dijual, uang muka, harga tanah, dan hak-hak serta kewajiban penjual dan pembeli serta dilampirkan gambar SITE PLAN yang di stabilo atau ditandai sebagai penunjuk (PETA) agar tidak keliru dengan batas-batas yang akan dialihkan oleh IR DULANG MARTAPA kepada ALWIJAYA selaku pembeli.Kemudian untuk menindak lanjuti kesepakatan untuk kemudian dituangkan dalam akta, IR DULANG MARTAPA dengan TONNY WIJAYA selaku kuasa dari ALWIJAYA menghadap Notaris SAN SMITH Pada tanggal 27 Juni 2008 agar membuat AKTA PENGIKATAN DIRI UNTUK MELAKUKAN JUAL BELI Nomor 165. Selanjutnya Notaris dan PPAT SAN SMITH Membuat AKTA PENGIKATAN DIRI UNTUK MELAKUKAN JUAL BELI Nomor 165 , akan tetapi Notaris SAN SMITH dituduh telah sekongkol dengan TONI WIJAYA agar menempatkan SITE PLAN atau gambar lokasi tanah yang tidak identik sesuai dengan kesepakatan. Kemudian penempatan SITE PLAN tersebut telah menimbulkan kerugian secara materi danimmaterialpada pihak IR DULANG MARTAPA selaku penjual. SITE PLAN yang tidak sesuai tersebut baru diketahui oleh IR DULANG MARTAPA pada tanggal 18 November 2008. Dari fakta yang ditemukan bahwa tanah yang dikuasi oleh pihak TONNY WIJAYA adalah $4.546 \mathrm{~m} 2$ sedangkan yang dijual oleh IR DULANG MARTAPA adalah 4.269,66 m2 disini terlihat selisih yang dikuasai dari pihak TONNY WIJAYA seluas 276,34 m2. Bentuk penguasaan yang dilakukan pihak TONNY WIJAYA dengan cara memgari diatas tanah seluas $4.546 \mathrm{m2}$ yang dimana seharusnya adalah 4.269,66 m2. Dari kasus tersebut diatas Notaris San Smith dituduh telah sekongkol dengan pihak Tonny Wijaya agar menempatkan site plan atau gambar lokasi tanah yang tidak sesuai dengan kesepakat. Maka dari itu Ir Dulang Martapa melaporkan Notaris San Smith ke poltabes Medan karena merasa dirugikan. 
Berdasarkan uraian kasus diatas San Smithselaku Notaris dijatuhi hukuman pidana yang dalam Putusan Pengadilan Negeri Medan Nomor 3036/PID.B/2009/ PN.MDN, dengan menjatuhkan pidana penjara selama 1 (satu) Tahun, sedangkan dalam Putusan Tinggi Medan Nomor 82/ PID/2010/PT-MDN, dengan menjatuhkan pidana penjara selama 2 (dua) Tahun. Notaris tersebut telah melanggar Pasal 266 ayat (1) Jo Pasal 55 ayat (1) Ke-1 KUHP yang bunyinya :

"Barang siapa menyuruh memasukkan keterangan palsu ke dalam suatu akta otentik mengenai sesuatu hal yang kebenarannya harus dinyatakan oleh akta itu, dengan maksud untuk memakai atau menyuruh orang lain memakai akta itu seolah-olah keterangannya sesuai dengan kebenaran, diancam, jika pemakaian itu dapat menimbulkan kerugian, dengan pidana penjara paling lama tujuh tahun."

Pasal 55 ayat (1)ke-1 KUHP, berbunyi: "Dipidana sebagai pelaku tindak pidana: ke-1 mereka yang melakukan, yang menyuruh melakukan, dan yang turut serta melakukan perbuatan."

Secara nyata Putusan Mahkamah Agungtersebut pada akhirnya membawa permasalahan dan ketidaksesuain norma terhadap beberapa hal yang tidak tepat, perlu dilakukan pengkajian kembali terhadap putusan ini. Pertimbangan hakim dalam mengambil keputusan tersebut yang mendorong penulis untuk mengkaji lebih dalam apakah putusan tersebut sudah sesuai dan tidak merugikan notaris sendiri sebagai pihak yang harus dilindungi. Pengkajian kembali secara akademis terhadap putusan ini karena penulis menganggap isi pasal 266 ayat (1) KUHP jo 55 ayat (1) ke-1 KUHP tidak tepat dan tidak dirasa adil untuk diterapkan dalam permasalahan ini.
Berdasarkan latar belakang tersebut diatas, maka permasalah dalam penelitian ini adalah sebagai berikut :

1. Mengapa dalam Putusan Mahkamah Agung Nomor 1099K/PID/2010 Notaris dipersalahkan serta dituntut untuk dapat dipertanggungjawabkan dalam pembuatan akta pihak?

2. Bagaimanakah akibat hukum terhadap Notaris pada Akta Pihak terkait Putusan Mahkamah Agung Nomor 1099 K/ PID/2010?

3. Apakah Putusan Mahkamah Agung Nomor 1099 K/PID/2010 sudah memenuhi rasa keadilan bagi Notaris dalam membuat Akta Pihak

\section{PEMBAHASAN}

\section{Dasar Pertimbangan Putusan Mahkamah Agung Nomor 1099/ PID/2010 Memutuskan Notaris Ber- salah Serta Dituntut Bertanggung- jawab Atas Pembuatan Akta}

\section{Posisi Kasus}

Kasus ini berawal dari Dulang Martapa yang sepakat untuk menjual, memindahkan, serta menyerahkan 17 (tujuh belas) kavling tanah yang terletak di Komplek Bukit Hijau Regency yang terdiri dari 21 (dua puluh satu) sertifikat Hak Guna Bangunan sertasebidang tanah seluas 4.269,66 M2 berdasarkan sertifikat Hak Guna Bangunan yang terdaftar di Kantor Pertanahan Kota Medan atas nama PT. Ira Widya Utama dengan Alwijaya. Dulang Martapa bersama Alwijaya membuat Akta Perjanjian Pendahuluan Untuk Jual Beli Nomor 138 pada tanggal 29 Mei 2008 di hadapan Notaris Roosmidar. Isi akta yang disepakati yaitu tentang batas tanah yang akan dijual, uang panjar sebesar 2 Milyar yang telah diterima oleh Dulang Martapa, harga tanah, hak dan kewajiban penjual dan pembeli serta lampiran berupa site plan yang ditandai (distabilo) tentang batas-batas tanah yang akan dialihkan 
oleh Dulang Martapa kepada Alwijaya. Pembayaran kedua yang jatuh tempo pada tanggal 29 Juni 2008, sebelumnya pihak Alwijaya memberitahukan kepada Dulang Martapa akan mengalihkan transaksi tersebut kepada PT. Mega Residence. Toni Wijaya selaku pihak dari PT. Mega Residence menghubungi Dulang Martapa untuk menghadap Notaris San Smith untuk menindak lanjuti Akta Perjanjian Pendahuluan Untuk Jual Beli Nomor 138 yang dibuat di hadapan Notaris Roosmidar.

Kedua pihak membuat Akta Pengikatan Diri Untuk Melakukan Jual Beli Nomor 165 yang isinya sama dengan Akta Perjanjian Pendahuluan Untuk Jual Beli Nomor 138. Akta berisi hal-hal yang disepakati yaitu untuk 17 (tujuh belas) kavling tanah seluas $19.210 \mathrm{M} 2$ dengan harga sebesar Rp. 1.562.175,- / M2 dengan jumlah harga keseluruhan sebesar Rp. 29.989.073.475,- sedangkan harga sebidang tanah dengan luas 4.269,66 M2 dengan harga Rp. 750.000,/ M2 dengan jumlah harga keseluruhan sebesar Rp. 3.202.245.000,- sehingga total harga adalah sebesar Rp. 33.191.318.475. Dulang Martapa menerima salinan akta dan ternyata setelah beberapa bulan baru disadari olehnya bahwa ada perubahan pada gambar atau site plan tersebut. Perubahan tersebut baru disadari pada tanggal 18 November 2008, di mana pada saat penandatanganan Akta No. 165 gambar site plan yang menjadi batas-batas objek untuk jual beli tidak sesuai dengan gambar pada Akta No. 138. Notaris San Smith dan Toni Wijaya telah bersekongkol untuk menempatkan site plan atau gambar lokasi tanah yang tidak identik atau tidak sama dengan yang disepakati sebelumnya di hadapan Notaris Roosmidar pada Akta Perjanjian Pendahuluan Untuk Jual Beli Nomor 138 di mana site plan sebagai satu kesatuan dengan akta tersebut.

Dulang Martapa merasa dirugikan baik secara materil dan immateril, di mana telah terjadi selisih luas tanah yang dikuasai oleh pihak Tony Wijaya seluas 276,34 M2 sehingga tanah yang dikuasai oleh Tony Wijaya seluas 4.546 M2 sedangkan yang dijual oleh Dulang Martapa seluas 4.269,66 M2. Penguasaan dilakukan pihak Tony Wijaya dengan cara memagari atau membuat pagar seng di atas tanah tersebut.

Berdasarkan dari uraian kasus tersebut diatas San Smith selaku Notaris didakwa oleh Jaksa Penuntut Umum telah turut serta memasukkan keterangan palsu ke dalam akta otentik atau memalsukan surat dan oleh karenanya San Smith dituntut Jaksa Penuntut Umum dengan hukuman 5 (lima) tahun penjara. Tuntutan Jakasa Penuntu Umum ini didasarkan pada pelanggaran yang dilakukan oleh San Smith selaku Notaris yang telah bersekongkol dengan salah satu pihak yaitu pembeli dalam perjanjian jual-beli untuk memasukkan suatu keterangan palsu ke dalam akta otentik yang mengakibatkan kerugian pada pihak lain yaitu penjual.

Majelis Hakim Pengadilan Negeri Medan yang memeriksa dan mengadili perkara dengan Register Nomor 3036/ PID.B/2009/PN.Mdn setelah mendengar tuntutan jaksa penuntut umum pada tanggal 4 Januari 2010, menjatuhkan pidana dengan amar putusan sebagai berikut:

1. Menyatakan Terdakwa San Smith, SH., tersebut telah terbukti secara sah dan meyakinkan bersalah melakukan tindak pidana Turut Serta menyuruh menempatkanketeranganpalsukedalam suatu akta otentik;

2. MenjatuhkanpidanaterhadapTerdakwa San Smith, SH., tersebut oleh karena itu dengan pidana penjara selama 1 (satu) tahun;

3. MenetapkanlamanyaTerdakwa ditahan dikurangkan seluruhnya dari pidana yang dijatuhkan;

4. Menetapkan Terdakwa tetap ditahan;

5. Menyatakan barang bukti berupa : 
Gde Yogi Yustyawan, Siti Hamidah \& Hariyanto Susilo| Aspek Pertanggungjawaban Pidana Notaris.

Akta Perjanjian Jual Beli 165 dengan lampiran lembar SITE PLAN dikembalikan kepada yang berhak melalui Majelis Pengawas Daerah Notaris Kota Medan;

6. Membebankan kepada Terdakwa membayar biaya perkara sebesar Rp. 1.000,- (seribu rupiah).

Majelis Hakim Pengadilan Tinggi Medan memeriksa dan mengadili perkara Register Nomor 82/PID/2010/PT-MDN, tanggal 25 Februari 2010 menjatuhkan pidana terhadap permohonan banding terdakwa dengan amar putusan sebagai berikut:

1. Menerima permintaan banding dari kuasa hukum terdakwa dan jaksa penuntut umum pada Kejaksaan Negeri Medan tersebut;

2. Mengubah putusan Pengadilan Negeri Medan Nomor 3036/Pid.B/2009/ PN.Mdn, tanggal 4 Januari 2010, yang dimintakan banding tersebut, sehingga amar selengkapnya berbunyi sebagai berikut:

1). Menyatakan terdakwa San Smith, SH tersebut telah terbukti secara sah dan meyakinkan bersalah melakukan tindak pidana "turut serta menyuruh

2). menempatkan keterangan palsu ke dalam suatu akta otentik";

3). Menjatuhkan pidana oleh karena itu terhadap terdakwa dengan pidana pejara selama 2 (dua) tahun;

4). Memerintahkan agar lamanya terdakwa ditahan dikurangi seluruhnya dari lamanya pidana yang dijatuhkan;

5). Menetapkan supaya terdakwa tetap ditahan;

6). Memerintahkan agar barang bukti berupa: Akta Perjanjian Jual Beli Nomor 165 dengan lampiran tanda terima sertifikat SHGB dan 2 (dua) lembar site plan dikembalikan kepada yangberhakmelaluiMajelisPengawas Daerah Notaris Kota Medan;
7). Membebani terdakwa untuk membayar biaya perkara pada kedua tingkat peradilan yang untuk tingkat banding sebesar Rp. 2000,- (dua ribu rupiah).

Putusan Mahkamah Agung RI Nomor 1099 K/PID/2010, tanggal 29 Juni 2010, amar putusan selengkapnya sebagai berikut :

1. Menolak permohonan kasasi dari Pemohon Kasasi : San Smith, SH., tersebut;

2. Membebankan Pemohon Kasasi/ Terdakwa tersebut membayar biaya perkara dalam tingkat kasasi sebesar Rp. 2.500,- (dua ribu lima ratus rupiah).

\section{Faktor Pertimbangan Hakim Terkait Putusan Mahkamah Agung Nomor 1099/PID/2010}

Dalam pertimbangan hukum Pengadilan Tinggi medan dalam putusannya menyatakan Majelis Hakim tingkat banding sependapat dan dapat menerima alasan-alasan dan bertimbangan hukum majelis tingkat pertama tentang terbuktinya dakwaan primer dan pertimbangan hukum majelis hakim pertama tersebut sudah tepat, benar dan cukup berlasan menurut hukum. Pertimbangan-pertimbangan tersebut didasari pada:

1. bahwa jika tidak ada kerjasama antara Terdakwa dengan Tony Wijaya dalam pembuatan Akta tersebut seharusnya Terdakwa dengan tegas menyebutkan dalam Aktanya luas tanah yang diperjanjikan untuk jual beli dan berapa luas yang telah dibayar dan berapa sisa dari tanah yang belum dibayar atau yang tidak dijual, tetapi Terdakwa dengan bersama-sama dengan Terdakwa Tonny Wijaya sengaja membuat Akta No. 165 tersebut, sehingga merupakan kekuatan bagi Tonny Wijaya memaksa Ir. Dulang MartapaatauPT.IraWidyaUtamauntuk menyerahkansisatanahyangsebenarnya 
tidak ikut dijual, hal tersebut terbukti darifaktayang diperoleh dariketerangan saksi-saksi dan keterangan Terdakwa baik dalam menanggapi keterangan saksi- saksi maupun ketika didengar keterangannya sebagai Terdakwabahwa Terdakwa sengajaataumenyadaridalam memasukkan Pasal 5 dan Pasal 12 dalam Akta No. 165 tersebut,dengan demikian unsur ini telah terbukti.

2. dasar pertimbangan hukum tidak tepat karna peraturan hukum yang digunakan untuk mengadili tidak tepat. Yakni notaris tidak bisa dipidanakan karna jabatannya menurut Undang-Undang Jabatan Notaris.

3. Pertimbangan hukum berdasarkan dari keterangan saksi dan Terdakwa dan tidak mendasarkan kepada keterangan ahli baik dalam berkas Penyidik maupun Berita Acara Sidang mengenai keterangan ahli didepan persidangan yang merupakan kewenangan dari Pengadilan Tinggi Medan untuk memeriksanya kembali sesuai dengan ketentuan Pasal 238 KUHpidana, akan tetapi hal tersebut tidak dilakukan oleh Pengadilan Tinggi Medan dan hanya menyatakan membenarkan saja atau sependapat dengan pertimbangan hukum Pengadilan Negeri Medan.

4. jika Terdakwa terbukti secara sah dan meyakinkanturutsertamenyuruh, maka Pengadilan harus dapat membuktikan siapa selaku pihak yang disuruh dan Pengadilan Tinggi Medan tidak ada satupun pertimbangan hukumnya yang membenarkan pertimbangan hukum Pengadilan Negeri Medan bahwa ada pihak yang disuruhuntukmenempatkan keterangan palsu dalam Akta No. 165 karena hal tersebut sangat bertentangan dengan maksud dariunsur Pasal266 ayat (1) KUHpidana Jo. Pasal 15 UndangUndang No. 30 tahun 2004 tentang Jabatan Notaris.

5. Tanggung Jawab Notaris Secara Perdata
6. Tanggung jawab Notaris secara perdata yang dalam hal ini menyangkut mengenai tanggung jawab terhadap akta yang dibuatnya. Perbuatan Notaris disini dapat diartikan dalam sifat aktif maupun sifat pasif. Sifat aktif yaitu Notaris melakukan perbuatan yang menimbulkan kerugian pada pihak lain. Sedangkan dalam arti pasif, Notaris tidak melakukan perbuatan yang merupakan keharusan, sehingga pihak lain menderita kerugian. Notaris melakukan kelalaian atau kesalahan dalam membuat akta dapat didasarkan pada Pasal 1365 KUHPerdata yang menyatakan tiap perbuatan melanggar hukum yang membawa kerugian kepada seorang lain, mewajibkan orang yang karena salahnya menerbitkan kerugian itu, mengganti kerugian itu.

7. Notaris dapat dikatakan melanggar hak subyektif orang lain apabila melakukan kesalahan atau kelalaian dalam pembuatan akta otentik, menurut Meyershak subyektif adalah wewenang khusus yang diberikan oleh hukum pada seseorang dimana dapat memperolehnya demi kepentingannya. Hak subyektifterdiridarihak kebendaan dan absolute, hak pribadi yang meliputi hak untuk mempunyai integritas terhadap jiwa dan kehidupan, hak atas kebendaan pribadi, hak atas kehormatan dan hak istimewa juga nama baik. ${ }^{5}$ Seseorang yang mengalami kerugian akibat kesalahan/kelalaian yang dilakukan oleh orang lain berhak mengajukan ganti rugi atas kerugian yang dideritanya kepada pengadilan negeri. Ganti rugi yang diminta dapat berupa ganti rugi yang bersifat materiil dan immateriil. Hakimlah yang menentukan berapa sepantasnya pihak yang menderita kerugian itu harus dibantu ganti ruginya, sekalipun pihak yang mengalami kerugian menuntut

${ }^{5}$ M.A Moegni Djojodirjo, Perbuatan melawan hukum, (Jakarta:Pradnya Paramita, 1982), hlm. 21. 
ganti rugi dalam jumlah yang tidak pantas. Dalam pertanggung jawaban seorang Notaris secara perdata, hakim dalam menangani perkara perdata yangmelibatkan Notaris mencari suatu kebenaran formil dari akta otentik yaitu kebenaran dari apa yang diperoleh berdasarkan apa yang dikemukakan oleh para pihak. Kebenaran ini digali dari fakta-fakta yang diajukan oleh para pihak. Kebenaran dalam ranah perdata sangat tergantung dari para pihak. Berbeda dengan ranah Hukum Pidana yang mencariadalah kebenaran materiil. Hakim tidak tergantung kepada apa yang dikemukakan oleh jaksa penuntut umum maupun oleh penasihat hukum terdakwa. Hakim bersifat aktif mencari kebenaran yang menurut fakta yang sebenarnya, bukan menurut apa yang dikemukakanolehjaksapenuntutumum maupun penasihat hukum terdakwa.

8. Peran Notaris disini hanya mencatat atau menuangkan suatu perbuatan hukum yang dilakukan oleh para pihak/ penghadap ke dalam akta. Notaris hanya mengkonstatir apa yang terjadi, apa yang dilihat, dan dialaminya dari para pihak/penghadap tersebut berikut menyesuaikan syarat-syarat formil pembuatan akta otentik kemudian menuangkannya kedalam akta. Notaris tidak diwajibkan untuk menyelidiki kebenaran isi materiil dari akta otentik tersebut. Hal ini mewajibkan Notaris untuk bersikap netral dan tidak memihak serta memberikan semacam nasihat hukum bagi klien yang meminta petunjuk hukum pada Notaris yang bersangkutan.NamunNotarisdapatjuga dipertanggung jawabkan atas kebenaran materiil suatu akta bila nasihat hukum yang diberikannya ternyata dikemudian hari merupakan suatu yang keliru. Serta apabila dalam pembuatan akta tersebut ternyata Notaris tidak memberikan akses mengenai suatu hukum tertentu yang berkaitan dengan akta yang dibuatnya sehingga salah satu pihak merasa tertipu atas ketidaktahuannya. Untuk itulah disarankan bagi Notaris untuk memberikan informasi hukum yang penting yang selayaknya diketahui klien sepanjang yang berurusan dengan masalah hukum. Lebih lanjut dijelaskan juga bahwa ada hal lain yang juga harus diperhatikan oleh Notaris, yaitu yang berkaitan dengan perlindungan hukum Notaris itu sendiri, dengan adanya ketidak hati-hatian dan kesungguhan yang dilakukan Notaris, sebenarnya Notaris telah membawa dirinya pada suatu perbuatan yang oleh undang undang harus dipertanggung jawabkan.

9. Tanggung Jawab Secara Administrasi

10.Tanggung Jawab secara administrasi terhadap seorang Notaris yang melakukan kesalahan/kelalaian dalam pembuatan akta otentik dapat dijatuhi sanksi administrasi. Secara garis besar sanksi administrasi dapat dibedakan menjadi 3 (tiga) macam yaitu sanksi reparatif adalah sanksi ini ditujukan untuk perbaikan atas pelanggaran tata tertib hukum. Dapat berupa penghentian perbuatan terlarang, kewajiban perubahan sikap/tindakan sehingga tercapainya keadaan semula yang ditentukan, tindakan memperbaiki sesuatu yang berlawanan dengan aturan. Contohnya paksaan untuk berbuat sesuatu untuk pemerintah dan pembayaranuang paksa yang ditentukan sebagai hukuman. Sanksi punitif adalah sanksi yang bersifat menghukum, merupakan beban tambahan. Sanksi hukuman tergolong dalam pembalasan, dan tindakan preventif yang menimbulkan ketakutan kepada pelanggar yang sama atau mungkin untuk pelanggar-pelanggar lainnya. Contohnya pembayaran denda kepada pemerintah, teguran keras. Dan sanksi regresif adalah sanksi sebagai reaksi atas sesuatu ketidaktaatan, dicabutnya hak atas sesuatu yang diputuskan menurut 
hukum, seolah-olah dikembalikan kepada keadaan hukum yang sebenarnya sebelum keputusan diambil. Contohnya pencabutan, perubahan atau penangguhan suatu keputusan. ${ }^{6}$

\section{Tanggung Jawab Notaris Secara Kode Etik Profesi Notaris}

Seorang Notaris yang melakukan profesinya harus berperilaku profesional, berkepribadian baik dan menjunjung tinggi martabat kehormatan Notaris dan berkewajiban menghormati rekan dan saling menjaga dan membela kehormatan nama baik korps atau organisasi. Sebagai profesi Notaris, ia bertanggungjawab terhadap profesi yang dilakukannya, dalam hal ini kode etik profesi. ${ }^{7}$ Profesi Notaris merupakan profesi yang berkaitan dengan individu, organisasi profesi, masyarakat pada umumnya dan Negara. Tindakan Notaris akan berkaitan dengan elemen-elemen tersebut oleh karenanya suatu tindakan yang keliru dari Notaris dalam menjalankan pekerjaannya tidak hanya akan merugikan Notaris itu sendiri saja namun dapat juga merugikan organisasi profesi, masyarakat dan Negara. Hubungan profesi Notaris dengan masyarakat dan Negara telah diatur dalam Undang-Undang Jabatan Notaris berikut peraturan perundang-undangan lainnya. Sementara hubungan profesi Notaris dengan organisasi profesi Notaris diatur melalui kode etik Notaris.

\section{Tanggung Jawab Notaris Secara Pidana}

Notaris dapat dikatakan melakukan pelanggaran dalam konteks Hukum Pidana sekaligus juga melanggar kode etik dan Undang-Undang Jabatan Notaris, sehingga syarat pemidanaan menjadi lebih kuat. Adapun pemidanaan terhadap

${ }^{6}$ J.B.J.M.Ten Berge, Besturen Door de Overheid, W.E.J. Tjeenk Qillink, Deventer, 1996, hlm. 390-391.

${ }^{7}$ Gnatius Ridwan Widyadharma, 1994, Hukum Profesi tentang Profesi Hukum, (Semarang: CV. Ananta, 1994), hlm. 133-134.
Notaris dapat saja dilakukan dengan batasan sebagai berikut :

a. Ada tindakan hukum dari Notaris terhadap aspek formal aktayang sengaja, penuh kesadaran dan keinsyafan serta direncanakan, bahwa akta yang dibuat dihadapan Notaris atau oleh Notaris bersama-sama(sepakat)untukdijadikan dasar untuk melakukan suatu tindak pidana.

b. Ada tindakan hukum dari Notaris dalam membuat akta di hadapan atau oleh Notaris yang jika diukur berdasarkan Undang-Undang Jabatan Notaris tidak sesuai dengan Undang-undang Jabatan Notaris.

c. Tindakan Notaris tersebut tidak sesuai menurutinstansiyangberwenang untuk menilai tindakan suatu Notaris, dalam hal ini MPN. ${ }^{8}$

Apabila seorang Notaris melakukan penyimpangan akan sebuah akta yang dibuatnya asehingga menimbulkan suatu perkara pidana maka Notaris harus mempertanggung jawabkan secara pidana apa yang telah dilakukannya tersebut. Pertanggungjawaban pidana lahir dengan diteruskannya celaan (verwijbaarheid) yang obyektif terhadap perbuatan yang dinyatakan sebagai tindak pidana berdasarkan Hukum Pidana yang berlaku, dan secara subyektif kepada pelaku yang memenuhi persyaratan untuk dapat dikenakan pidana karena perbuatannya itu. ${ }^{9} \mathrm{Hal}$ tersebut didasarkan pada asas tidak dipidana jika tidak ada kesalahan atau "actus non facit reum nisi mens sit rea". Orang tidak mungkin dimintakan pertanggungjawaban dan dijatuhi pidana jika tidak melakukan kesalahan. ${ }^{10}$ Akan tetapi seseorang yang melakukan perbuatan pidana, belum tentu dapat dipidananya. Orang yang melakukan

\footnotetext{
${ }^{8}$ Habib Adjie, Op.Cit, hlm. 124-125.

9 Dwidja Priyatno,Kebijakan Legislasi tentang Sistem Pertanggungjawaban Pidana Korporasi di Indonesia, (Bandung: CV. Utomo, 2004), hlm. 30.

${ }^{10} \mathrm{Ibid}, \mathrm{hlm} .56$.
} 
perbuatan pidana akan dipidanya apabila dia mempunyai kesalahan.

Terjadinya pemidanaan terhadap Notaris berdasarkan akta yang dibuat oleh atau di hadapan Notaris sebagai bagian dari pelaksanaan tugas jabatan atau kewenangan Notaris, tanpa memperhatikan aturan hukum yang berkaitan dengan tata cara pembuatan akta dan hanya berdasarkan ketentuan Kitab Undang-Undang Hukum Pidana saja, menunjukkan telah terjadinya kesalahpahaman ataupenafsiran terhadap kedudukan Notaris sedangkan akta otentik yang dibuat oleh Notaris sebagai alat bukti dalam Hukum Perdata. Sanksi pidana merupakan ultimum remedium yaitu obat terakhir, apabila sanksi atau upaya-upaya pada cabang hukum lainnya dianggap tidak mempan. ${ }^{11}$ Penjatuhan sanksi pidana terhadap Notaris dapat dilakukan sepanjang batasan-batasan sebagaimana tersebut dilanggar, artinya disamping memenuhi rumusan pelanggaran yang tersebut dalam Undang-Undang Jabatan Notaris dan kode etik jabatan Notaris juga harus memenuhi rumusan yang tersebut dalam KUHpidana. Apabila tindakan pelanggaran yang dilakukan oleh Notaris memenuhi rumusan suatu tindak pidana, tetapi jika ternyata berdasarkan UndangUndang jabatan Notaris dan menurut penilaian dari Majelis Pengawas Daerah bukan suatu pelanggaran. Maka Notaris yang bersangkutan tidak dapat dijatuhi hukuman pidana, karena ukuran untuk menilai sebuah akta harus didasarkan pada Undang-Undang Jabatan Notaris dan kode etik jabatan Notaris.

\section{Akibat Hukum Terhadap Notaris Pada Akta Pihak Terkait Putusan Mahkamah Agung Nomor 1099 K/PID/2010}

\section{Akibat Hukum Terkait Kewenangan Notaris}

${ }^{11}$ Habib Adjie, Jurnal Renvoi, Nomor 10-22 Tanggal 3 Maret 2005, hlm. 126.
Kewenangan merupakan suatu tindakan hukum yang diatur dan diberikan kepada suatu jabatan berdasarkan peraturan perundang-undangan yang berlaku yang mengatur jabatan tersebut. Wewenang Notaris memiliki batasan sebagaimana diatur dalam perundangundangan yang mengatur jabatan pejabat yang bersangkutan.Setiap perbuatan pemerintah disyaratkan harus bertumpu pada kewenangan yang sah. Tanpa ada kewenangan yang sah seorang Pejabat ataupun Badan Tata Usaha Negara tidak dapat melaksanakan suatu perbuatan pemerintahan. Oleh karena itu kewenangan yang sah merupakan atribut bagi setiap Pejabat ataupun bagi setiap Badan. ${ }^{12}$

Jabatan memperoleh wewenang melalui tiga sumber yaitu atribusi, delegasi dan mandat. ${ }^{13}$ Kewenangan yang diperoleh dengan cara atribusi, apabila terjadi pemberian wewenang pemerintahan yang baru oleh suatu ketentuan perundang- undangan dan perundangundanganlah yang menciptakan suatu wewenang pemerintahan yang baru. Kewenangan secara delegasi merupakan pemindahan/ pengalihan wewenang yang ada berdasarkan suatu peraturan perundang-undangan atau aturan hukum. Kewenangan mandat sebenarnya bukan pengalihan atau pemindahan wewenang tapi karena yang berkompeten berhalangan.

Berdasarkan Undang-Undang Jabatan Notaris tersebut ternyata Notaris sebagai Pejabat Umum memperoleh kewenangan secara atribusi, karena wewenang tersebut diciptakan dan diberikan oleh UndangUndang jabatan Notaris sendiri. Jadi, wewenang yang diperoleh Notaris bukan berasal dari lembaga lain, misalnya dari

\footnotetext{
${ }^{12}$ Lutfi Effendi, Pokok-Pokok Hukum Administrasi, (Malang: Bayumedia Publishing, 2004), hlm. 77.

${ }^{13}$ Philipus M. Hadjon, Pengantar Hukum Administrasi Indonesia Introduction to the Indonesia Administrative Law, (Yogyakarta: Gajah Mada University Press, 1987), hlm. 139.
} 
Departemen Hukum dan Hak Asasi Manusia. ${ }^{14} J a d i$ Notaris memiliki legalitas untuk melakukan tindakan hukum dalam membuat akta otentik.

\section{Akibat Hukum Terkait Kewajiban No- taris}

Seorang Notaris dalam menjalankan profesinya memiliki kewajiban-kewajiban sebagaimana diatur dalam UndangUndang Nomor 2 Tahun 2014 Tentang Perubahan Atas Undang-Undang Nomor 30 Tahun 2004. Seorang Notaris wajib bertindak jujur, seksama, dan tidak memihak. Notaris perlu memperhatikan apa yang disebut perilaku profesi yang memiliki unsur-unsur yaitu perilaku Notaris harus memiliki integritas moral yang mantap, harus jujur bersikap terhadap klien maupun diri sendiri, sadar akan batas-batas kewenangannya dan tidak bertindak semata-mata berdasarkan pertimbangan uang. ${ }^{15}$ jabatan yang dipangku Notaris adalah jabatan kepercayaan dan justru oleh karena itu seseorang bersedia mempercayakan sesuatu kepadanya. Salah satu bentuk jabatan kepercayaan yaitu dengan melihat Notaris yang mempunyai kewajiban untuk merahasiakan segala sesuatu tentang akta yang dibuatnya sesuai dengan sumpah atau janji yang telah diucapkan sebelum diangkat sebagai Notaris kecuali undangundang menentukan lain. ${ }^{16}$ Dengan demikian, batasannya hanya undangundang saja yang dapat memerintahkan Notaris untuk membuka rahasia isi akta dan keterangan ataupun pernyataan yang diketahui Notaris yang berkaitan dengan pembuatan akta yang dimaksud. Hal ini sesuai dengan isi Pasal 16 ayat (1) huruf f Undang-Undang Jabatan Notaris yaitu: "merahasiakan segala sesuatu

${ }^{14}$ Habib Adjie, Merajut Pemikiran Dalam Dunia Notaris \& PPAT, (Bandung: PT. Citra Aditya Bakti, 2014), hlm. 78.

${ }^{15}$ Liliana Tedjosaputro, Etika Profesi dan Profesi Hukum, (Semarang: Aneka Ilmu, 2003), hlm. 93.

16 G.H.S Lumban Tobing,Peraturan Jabatan Notaris, (Jakarta: Erlangga, 1983),hlm. 117. mengenai Akta yang dibuatnya dan segala keterangan yang diperoleh guna pembuatan Akta sesuai dengan sumpah/ janji jabatan, kecuali undang-undang menentukan lain".

\section{Akibat Hukum Terkait Sanksi Bagi Notaris}

Secara umum di Indonesia dikenal sekurang-kurangnya tiga jenis sanksi hukum yaitu sanksi Hukum Perdata, sanksi Administrasi, dan sanksi Pidana. Dalam Pasal 84 dan Pasal 85 UndangUndang No. 2 Tahun 2014 tentang perubahan atas Undang- Undang No. 30 Tahun 2004 tentang Jabatan Notaris diatur bahwa ketika Notaris dalam menjalankan tugas jabatannya terbukti melakukan pelanggaran, maka notaris dapat dikenai atau dijatuhi sanksi, berupa sanksi perdata, administrasi, dan kode etik jabatan Notaris, dan sanksi-sanksi tersebut telah diatur sedemikian rupa, baik sebelumnya dalam Peraturan Jabatan Notaris, dan sekarang dalam UndangUndang Jabatan Notaris dan Kode Etik Jabatan Notaris, tidak mengatur adanya sanksi pidana terhadap notaris.

Dalam praktik ditemukan kenyataan bahwa suatu tindakan hukum atau pelanggaran yang dilakukan Notaris sebenarnya dapat dijatuhi sanksi administrasi atau perdata atau kode etik jabatan Notaris, namun kemudian ditarik atau dikualifikasikan sebagai suatu tindak pidana yang dilakukan oleh notaris.Aspekaspek tersebut jika terbukti dilanggar oleh Notaris maka notaris yang bersangkutan dapat dijatuhi sanksi perdata atau administratif. Jika aspek- aspek tersebut dapat dibuktikan dapat dijadikan dasar untuk menjatuhkan sanksi administratif dan sanksi perdata terhadap Notaris. Di sisi lain aspek- aspek tersebut dapat dijadikan dasar untuk mempidanakan Notaris dengan dasar notaris telah membuat surat palsu atau memalsukan akta dengan 
kualifikasi sebagai suatu tindak pidana yang dilakukan oleh Notaris. ${ }^{17}$

\section{Analisis Putusan Mahkamah Agung Nomor 1099/PID/2010 Dalam Perspe- ktif Keadilan}

\section{Indikator Keadilan Bagi Notaris}

Keadian adalah indikator menempatkan sesuatu sesuai dengan porsinya, pada kasus ini rasa keadilan dirasa penulis kurang karena Putusan Mahkamah Agung Nomor 1099/PID/2010 dijatuhkan tanpa melihat terdakwa sebagai subjek hukum yang karena jabatannya dilindungi sendiri oleh Undang-Undang jabatan Notaris. Dasar putusan hakim tersebut dirasa tidak adil bagi Notaris. Hal ini tentu menimbulkan ketakutan tersendiri bagi Notaris dalam menjalankan jabatannya padahal segala hal yang berhubungan dengan jabatannya itu sudah diatur didalam Undang-Undang Jabatan Notaris.

Suatu pengikatan akta jual beli yang dibuat dihadapan seorang Notaris/PPAT itu bukan hanya mempunyai kegunaan untuk membuktikan bahwa pihak-pihak tertentu telah memberikan keteranganketerangan tertentu dihadapan Notaris/ PPAT, melainkan juga bahwa mereka itu telah mengadakan suatu perikatan sesuai dengan yang ditentukan dalam pasal 1458 KUHperdata, Akta tersebut juga membuktikan tentang besarnya nilai jual beli, sehingga Akta Notaris/ PPAT juga mempunyai kegunaan untuk membuktikan kebenaran yang telah dikemukakan oleh para pihak.

Pelanggaran terhadap pasal 266 Ayat (1) KUHpidana hanya dapat disangkakan kepada Notaris/PPAT manakala Notaris/ PPAT mengetahui bahwa keterangan yang diminta para pihak untuk dimasukan kedalam aktanya tidak benar, tetapi Notaris/PPAT tetap bersedia membuatkan Akta tersebut, sehingga

${ }^{17}$ Habib Adjie, Hukum Notaris Indonesia, (Bandung: Refika Aditama, 2014), hlm. 25
Notaris/PPAT dalam hal ini dapat dijerat telah membantu melakukan kejahatan Pasal 266 Ayat (1) KUHpidana dengan ancaman maksimal pidananya yang dapat dijatuhkan untuk perbuatan membantu kejahatan Pasal 266 Ayat (1) KUHpidana dikurangi sepertiganya Pasal 57 Ayat (1) KUHpidana. Untuk menghindari terjerat terdakwa melakukan tindak pidana pasal 266 Ayat (1) KUHpidana baiknya sejak awal para penghadap mengutarakan dengan tegas niatnya untuk melakukan perbuatan hukum.

\section{SIMPULAN}

Berdasarkan hasil dan pembahasan dalam penulisan ini, dapat disimpulkan bahwa tanggung jawab Notaris secara pidana atas akta yang dibuatnya tidak diatur dalam Undang-Undang Jabatan Notaris namun tanggung jawab Notaris secara pidana dikenakan apabila Notaris melakukan perbuatan pidana. UndangUndang Jabatan Notaris hanya mengatur sanksi atas pelanggaran yang dilakukan oleh Notaris. sanksi tersebut dapat berupa akta yang dibuat oleh Notaris tidak memiliki kekuatan otentik atau hanya mempunyai kekuatan sebagai akta di bawah tangan. Terhadap Notarisnya sendiri dapat diberikan sanksi yang berupa teguran hingga pemberhentian dengan tidak hormat. Undang undang jabatan Notaris hanya mengatur mengenai tanggungjawab Notaris dalam ranah perdata dan administrasi.

Akibat hukum terkait Putusan Mahkamah Agung Nomor 1099/PID/2010 sanksi yang dijatuhkan kepada Sam Smith selaku Notaris berupa sangsi perdata dan administrasi yakni diatur dalam pasal 84 dan 85 Undang-Undang jabatan Notaris yang menyebutkan bahwa sanksi perdata berupa penggantian biaya, ganti rugi atau bunga dapat dituntut terhadap Notaris harus didasarkan pada suatu hubungan hukum antara Notaris dengan para pihak yang menghadap Notaris, jika ada pihak 
yang merasa dirugikan sebagai akibat langsung dari suatu Akta Notaris, maka yang bersangkutan dapat menuntut secara perdata terhadap Notaris, dengan demikian tuntutan penggantian biaya, ganti rugi dan bunga terhadap Notaris tidak berdasarkan atas penilaian atau kedudukan suatu alat bukti yang berubah karena melanggar Pasal 84 UndangUndang Jabatan Notaris, tapi hanya dapat didasarkan pada hubungan hukum yang ada atau yang terjadi antara Notaris dengan Para Penghadap. Sedangkan sanksi administrasi berupa teguran lisan, teguran tertulis, pemberhentian sementara, pemberhentian dengan hormat, dan pemberhentian tidak hormat.

Keadilanadalahindikatormenempatkan sesuatu sesuai dengan porsinya, pada kasus ini rasa keadilan dirasa penulis kurang karena Putusan Mahkamah Agung Nomor 1099/PID/2010 dijatuhkan tanpa melihat terdakwa sebagai subjek hukum yang karena jabatannya dilindungi sendiri oleh Undang-Undang jabatan Notaris. Dasar putusan hakim tersebut dirasa tidak adil bagi Notaris. Hal ini tentu menimbulkan ketakutan tersendiri bagi Notaris dalam menjalankan jabatannya padahal segala hal yang berhubungan dengan jabatannya itu sudah diatur didalam Undang-Undang Jabatan Notaris.

Berdasarkan hasil penelitian ini maka penulisberpendapatHarusadaharmonisasi hukum antara pertanggungjawaban perdata,administrasi dan pidana terhadap Notaris. Terutama dalam aspek pidana, sampai sejauh mana Notaris dapat dimintakan pertanggungjawabannya jika kemudian akta yang dibuatnya bermasalah di kemudian hari.

Pelaksanaan penegakan hukum harus berdasarkan ketentuan aturan hukum. Jika tidak maka dapat berakibat batal demi hukum. Keharusan penegakan hukum dimaksudkan agar para penegak hukum tidak berlaku sewenang-wenang dalam memutuskan.
Pertimbangan hakim Harus bisa didasarkan bahwa subjek hukum yang bersengketa bukanlah Notaris. Disini Notaris hanya menjalankan jabatannya yang sudah sesuai dengan UndangUndang Jabatan Notaris.

\section{DAFTAR PUSTAKA}

Abdulkadir Muhammad, 1992. Hukum Perikatan, Bandung: Citra AdityaAhmad Rifai, 2010. Penemuan Hukum Oleh Hakim Dalam Persfektif Hukum Progresif, Jakarta: Sinar GrafikaAndi Hanzah, 2005. Kamus Hukum, Ghalia Indonesia.

Donald Albert Rumokoy dan Frans Maramis, 2014. Pengantar Imu Hukum, Jakarta: rajawali persDwidja Priyatno, 2004. Kebijakan Legislasi tentang Sistem Pertanggungjawaban Pidana Korporasi di Indonesia, Bandung: CV. UtomoEis Fitriyana Mahmud, 2013. "Batas-batas Kewajiban Ingkar Notaris dalam Penggunaan Hak Ingkar pada Proses Peradilan Pidana", Jurnal, Program Studi Magister Kenotariatan, Fakultas Hukum, Universitas Brawijaya, Malang.

G.H.S Lumban Tobing, 1983. Peraturan Jabatan Notaris, Jakarta: Erlangga,Gnatius Ridwan Widyadharma, 1994, Hukum Profesi tentang Profesi Hukum, Semarang: CV. Ananta.

H. Chaerudin, 1999. Filsafat Suatu Iktisar, Cianjur: FH UNSUR.

H. D. Van Wijk/Willem Konijnenbelt, 1990. Hoolfdstukken van Adminstratief Recht, Uitgeverij Lemma BW, Utrecht.

Habib Adjie, 2009. Hukum Notaris 
Gde Yogi Yustyawan, Siti Hamidah \& Hariyanto Susilo| Aspek Pertanggungjawaban Pidana Notaris.

Indonesia, Bandung: PT Refika Aditama.

Habib Adjie, 2014. Hukum Notaris Indonesia, Bandung: Refika Aditama.

Habib Adjie, 2008. Hukum Notaris Indonesia, Tafsir Tematik terhadap UU No. 30 Tahun 2004 Tentang Jabatan Notaris, Bandung: Refika Aditama.

Habib Adjie, 2008. Hukum Notaris Indonesia, Tafsir Tematik Terhadap UU No. 30 Tahun 2004 tentang Jabatan Notaris, Cetakan Pertama, Bandung : PT Refika Aditama.

Habib Adjie, 2011. Kebatalan dan Pembatalan Akta Notaris, Bandung: PT Refika Aditama.

Habib Adjie, 2009. Meneropong Khazanah Notaris dan PPAT Indonesia, Bandung: PT Citra Aditya Bakti.

Habib Adjie, 2014. Merajut Pemikiran Dalam Dunia Notaris \& PPAT, Bandung: PT. Citra Aditya Bakti.

Habib Adjie, 2009. Sekilas Dunia Notaris \& PPAT Indonesia, Bandung: Mandar Maju.

Hans kelsen, 2011. General Theory of Law and state, diterjemahkan oleh Rasisul Muttaqien, Bandung: Nusa Media.

Heikhal A.S. Pane, 2009. Penerapan Uitvoerbar bij Voorraad dalam Putusan Hakim pada Pengadilan Tingkat Pertama (Studi kasus: Putusan Perkara Perdata Register Nomor 89/ PDT.G/2005/PN.TNG), (Tesis Magister Hukum Fakultas Hukum Universitas Indonesia,)

Ilhami Bisri, 2005. Sistem Hukum Indonesia, Jakarta, PT Raja
Grafindo Persada.

Irwan Soerodjo, 2003. Kepastian Hukum Hak Atas Tanah di Indonesia, .Surabaya: Arkola.

J.B.J.M.Ten Berge, 1996. Besturen Door de Overheid, W.E.J. Tjeenk Qillink, Deventer. Jimly Asshidiqie dan Ali Safaat, 2006. Teori Hans Kelsen Tentang Hukum, Jakarta: Sekretariatan Jendral dan Kepaniteraan Mahkamah Konstitusi RepublikIndonesia.

Kahar Masyhur, 1985. Membina Moral dan Akhlak, Jakarta: Kalam MuliaKomar Andasasmita, 1981. Notaris Dengan Sejarah, Peranan, Tugas Kewajibannya, Rahasia Jabatannya, Bandung: Sumur.

KUHP, (PT. Bina Aksara 1985), cetakan ke-14, 1985.

L.J. Van Apeldoorn, 1996. Pengantar Ilmu Hukum, Jakarta: Pradnya Paramita cetakan 26.

Liliana Tedjosapatro, 1991. Mal Praktek Notaris dan Hukum Pidana, Semarang: CV Agung.

Liliana Tedjosaputro, 2003. Etika Profesi dan Profesi Hukum, Semarang: Aneka IlmuLilik Mulyadi, 2010. Putusan Hakim dalam Hukum Acara Pidana: Teori, Praktik, Tehnik Penyusunan dan Permasalahannya. Citra Adtya Bakti : Bandung.

Lutfi Effendi, 2004. Pokok-Pokok Hukum Administrasi, Malang: Bayumedia Publishing.

M. Luthfan Hadi Darus, 2017. Hukum Notariat dan Tanggungjawab Jabatan Notaris, Yogyakarta: UII Press.

M. Solly Lubis, 1994. Filsafat Mmu dan Penelitian, Bandung: Mandar 
Maju.

M. Yahya Harahap, 2000. Pembahasan Permasalahan dan Penerapan KUHAP (Penyidikan dan Penuntutan), Edisi Kedua, Jakarta, Sinar Grafika.

M.A Moegni Djojodirjo, 1982. Perbuatan melawan hukum, Jakarta:Pradnya Paramita.

Masri Singarimbun dan Sofian Effendi, 1998. Metode Penelitian Sosial, Jakarta: LP3ES.

Mukti Fajar dan Yulianto Achmad, 2010. Dualisme Penelitian Hukum Normatif \& Empiris, Yogyakarta: Pustaka Pelajar.

Mulyoto, 2014. Pertanggung jawaban Notaris-PPAT Dalam Menjalankan Tugas Jabatannya, Yogyakarta: Cakrawala.

Nico, 2003. Tanggungjawab Notaris Selaku Pejabat Umum, Yogyakarta: Center for Documentation and Studies of Business Law.

Pasal 266 Ayat (1) Kitab UndangUndang Hukum Pidana

Peter Mahmud Marzuki, 2010. Penelitian Hukum, Edisi ke-1 Cet VI, (Jakarta: Kencana,)

Philipus M. Hadjon, 1987. Pengantar Hukum Administrasi Indonesia Introduction to the Indonesia Administrative Law, Yogyakarta: Gajah Mada University Press.

R Soegondo, 1991. Hukum Pembuktian, (Jakarta: PT Pradnya Paramita,)

R. Soegondo Notodisoerjo, 1993. Hukum Notariat di Indonesia Suatu Penjelasan, Jakarta: Raja Grafindo Persada.

R. Soesilo, 1988. Kitab Undang-undang
Hukum Pidana (KUHP) serta komentarkomentarnya lengkap pasal demi pasal, Politia Bogor, cetakanulang ke- sepuluh.

RidwanH.R., 2006.Hukum Administrasi Negara, Jakarta: Raja Grafindo Persada.

Ronny Hanitijo Soemitro, 1982. Metodologi Penelitian Hukum, Semarang: Ghalia Indonesia.

Salim H. S., 2010. Perkembangan Teori Dalam Imu Hukum, Jakarta: Rajawali Pers.

Salim H. S, 2015. Teknik Pembuatan Akta Satu (konsep Teoritis, Kewenangan Notaries, Bentuk Dan Minuta Akta), Jakarta: Raja Grafindo Persada.

Setiawan, "Hak Ingkar Dari Notaris dan Hubungannya Dengan KUHP", Suatu Kajian Uraian Yang Disajikan Dalam Kongres INI di Jakarta.

Sjaifurrachman dan Habib Adjie, 2011. Aspek Pertanggungjawaban Notaris dalam Pembuatan Akta, Bandung: Mandar Maju.

Soekidjo Notoatmojo, 2010. Etika dan Hukum Kesehatan, Jakarta: Rineka Cipta.

Sudikno Mertokusumo, 2006. Hukum Acara Perdata Indonesia, Yogyakarta: Liberty.

Sudikno Mertokusumo, 1999. Mengenal Hukum Suatu Pengantar, Yogyakarta: Liberty.

Tan Thong Kie, 2000. Buku I Studi Notariat dan Serba Serbi Praktek Notaris, Jakarta: Ichtiar Baru Van Houve.

Tim Penyusun Kamus Pusat Pembinaan dan Pengembangan Bahasa, Kamus besar Bahasa Indonesia. 
Gde Yogi Yustyawan, Siti Hamidah \& Hariyanto Susilo| Aspek Pertanggungjawaban Pidana Notaris.

Titik Triwulan dan Shinta Febrian, 2010.

Perlindungan Hukum Bagi

Pasien, Jakarta: Prestasi Pustaka.

Zainal Arifin Hoesein, 2016. Kekuasaan

Kehakiman Di Indonesia,

Malang: Setara Press. 